Pinisi Discretion Review

Volume 4, Issue 2, March 2021 Page. 255- 266

ISSN (Print): 2580-1309 and ISSN (Online): 2580-1317

\title{
Analisys of The Effectiveness of The Utilization of Electronic Government On State-Owned Enterprises
}

\author{
Andi Rahmatiah \\ Public Administration, Universitas Pepabri Makassar \\ Email: maynamemay@gmail.com
}

(Received: January-2021; Reviewed: February-2021; Accepted: March-2021;

Avalaible Online: March-2021; Published: March-2021)

This is an open access article distributed under the Creative Commons Attribution License

CC-BY-NC-4.0 @2021 by author (https://creativecommons.org/licenses/by-nc/4.0/)

\begin{abstract}
The use of electronic government (e-gov) of face and finger access control has been implemented at PT. PLN Tello Sector Makassar City and is expected to be able to streamline employee performance. The purpose of this study, is to analyze the effectiveness of the use of face and finger access control at PT. PLN Tello Sector Makassar City. This research method uses quantitative research types with quantitative descriptive research types. Data collection techniques using questionnaires in the form of a checklist and using descriptive analysis techniques. The results showed that the effectiveness of the use of face and finger access control at PT. PLN Tello Sector Makassar City is in quite good category, based on the analysis of target achievement indicators, adaptability, job satisfaction, and responsibility.
\end{abstract}

Keywords: Effectiveness; electronic government; On State-Owned Enterprises

\section{INTRODUCTION}

A government agency is an organization consisting of a group of people who are selected based on certain procedures in carrying out tasks within the state as a form of public service (general). Every government agency or organization has goals that can be achieved if human resources can be managed or mobilized effectively and efficiently (Farida, 2017; Ismail et al., 2016; M. Konisky David, 2001; Sahlin-Andersson, 2011; Sunarsi, 2019; Sunarsi \& Erlangga, 2020; Zainal et al., 2018).

One of the ways that can be taken to make the work of civil servants or the state civil apparatus (ASN) effective is through the attendance system. Along with the development of technology and the implementation of the use of electronic government (e-gov), there have been developments that initially only manual attendance developed into biometric attendance such as face and finger access control (Hadiana, 2019).

Face and finger access control has also been implemented at PT. PLN Tello Sector Makassar City, which is a State-Owned Enterprise (BUMN) which is engaged in providing 
electricity. The provision of electricity includes several activities, namely: generation, distribution, distribution and also planning, and a construction of electricity supply facilities, as well as the development of electricity supply (Mohd et al., 2008).

The use of face and finger access control at PT. PLN Tello Sector Makassar City is expected to streamline the performance of employees at the office. However, after being implemented for approximately 4 (four) years, the effectiveness of using face and finger access control cannot be said to be running effectively and efficiently, especially in increasing employee discipline (Bardach \& Patashnik, 2019).

This research is important to do by researchers so that it can be used as a recommendation for companies to be able to determine the effectiveness of the use of face and finger access control at PT. PLN Tello Sector Makassar City. Based on the description of the problems that have been stated, the purpose of this study is to analyze the effectiveness of the use of face and finger access control at PT. PLN Tello Sector Makassar City (Siegel et al., 2003) (Jain et al., 2016).

In general, e-government (e-gov) itself is an internet-based information management system and community service management. There are several similarities in terms of the characteristics of the definition of e-government, namely: (1) It is a new (modern) government interaction mechanism, both with internal parties of government itself and with external parties of government such as other government agencies, the public, and the private sector. interested (stakeholders); (2) Involves the use of information and communication technology (ICT), especially the internet as a tool; (3) The objectives are to improve service quality, efficiency, effectiveness, transparency and accountability; and (4) The objects are government services (Akman et al., 2005).

In general, e-gov is defined as: electronic government (also called e-gov, digital government, online government, or transformational government) is the use of information technology by the government to provide information and services for its citizens, business affairs, and other matters. which is related to government. E-gov can be applied to the legislative, judiciary, or public administration, to increase internal efficiency, deliver public services, or process democratic governance (Akman et al., 2005).

There are 4 (four) types of e-government relations (Indrajit, 2016)namely:

1. Government to Citizens (Type $\mathrm{G}$ to $\mathrm{C}$ )

This type of $\mathrm{G}$ to $\mathrm{C}$ is the most common e-government application, where the government builds and implements various portfolios of information technology with the main objective of improving interaction relations with the public (the people). In other words, the main objective of developing a $\mathrm{G}$ to $\mathrm{C}$ type of e-government application is to bring the government closer to its people through various access channels so that people can easily reach their government to fulfill various daily service needs.

2. Government to Business ( Type G to B)

One of the main tasks of a government is to form a conducive business environment so that we the wheels of a country's economy can run properly. In carrying out daily activities, business entities such as private companies require a lot of data and information that is owned by the government. In addition, the person concerned must also interact with various state institutions because it is related to the rights and obligations of his organization as aprofit-oriented entity. The need for good relations between the government and the business community is not only aimed at facilitating business practitioners in running the wheels of their company, but also there are many things that can benefit the government if there is a good and effective interaction relationship with private industry

3. Government to Governments (Type G to G) 
In this era of globalization, it is clear tat there is a need for countries to communicate with each other more intensely from day to day. The need to interact between one government and the government every day does not only revolve around diplomacy, but also goes further to facilitate cooperation between countries and cooperation between state entities (society, industry, companies, etc.) in carrying out matters relating to trade administration, political proceses, mechanisms for social and cultural relations and so on.

4. Government to Employees (Type $\mathrm{G}$ to $\mathrm{E}$ )

In the end, e-Government applications are also intended to improve the performance and welfare of civil servants or government employees who work in a number of institutions as public servants.

The concept of effectiveness according to the Big Indonesian Dictionary, comes from the word effective which means effect, influence, effect, or result. So, effectiveness is an activity, effectiveness, there is conformity regarding an activity of a person carrying out a task or job based on the goals to be achieved. Effectiveness is a key element in achieving the goals or objectives that have been determined in any organization, activity or program (Lee \& Sukoco, 2007).

Basically, effectiveness shows at the level of achieving results, often or always associated with the notion of efficiency, even though in fact there are differences between the two. Effectiveness emphasizes the results achieved, while efficiency looks more at how to achieve the results achieved then compares the input and output (Siagian, 2015).

Effectiveness according to Marnis (Priyono, 2016), is communication whose process reaches the goals that have been planned based on budgeted costs, predetermined time and the number of assigned personnel. The same is the case according to (Siagian, 2015), which says that effectiveness is the use of existing resources, facilities and infrastructure based on a certain number of consciously predetermined goods to produce a number of goods for the services of the activities carried out.

Based on this definition, it can be concluded that effectiveness is related to the use of various resources based on what has been targeted to achieve a goal.

The effectiveness of face and finger access control is a measurement of the achievement of a predetermined goal, namely in relation to face and finger access control (Bazen \& Gerez, 2002). Face and finger access control is a type of biometric attendance machine that uses employee fingerprints and face detection methods to record the attendance list of all employees. With this biometric attendance machine, it can be used to replace manual attendance machines.

Face and finger access control is equipped with a time recording feature. This feature allows us to know the timeliness of employees entering and leaving the office. For example, a company or agency has set the office hours at 07.35 . Then when an employee comes and makes attendance at 08:00, the biometric attendance machine will automatically record the employee's tardiness. This states that it is important for every company that wants to improve the discipline of its employees to use a fingerprint attendance machine such as face and finger access control.

The criteria or indicators of effectiveness ((Tangkilisan Nogi Hessel, 2015), namely:

1. Achievement of targets

The achievement of targets here is how an organization can set targets and then realize them well. This can be proven from the results of the implementation of organizational goals in achieving targets based on predetermined goals.

2. Adabtability

The ability to adapt is necessary in an organization because the success of an organization can also be seen from the extent to which an organization is able to adapt to the changes that occur, both changes from within the organization (internal) and outside the organization (external). 


\section{Job satisfaction}

Job satisfaction is a condition that is felt by all members of an organization or employees in an agency that is able to provide a sense of comfort and motivation to increase the performance of an organization or agency.

4. Responsibility

The organization can carry out the tasks and authorities it has carried out in accordance with the provisions that have been made next, and is able to face and solve various problems that occur in its work.

As for other indicators of effectiveness according to (Hakim, 2012), namely: (1) There is clarity of program objectives; (2) There is clarity regarding the strategy for achieving program objectives; (3) There is a formulation of a good program policy; (4) There is a proper programming; (5) Provision of facilities and infrastructure; (6) Program operational effectiveness; (7) The functional effectiveness of the program; (8) Effectiveness of program objectives; (9) Effectiveness of program targets; (10) Individual effectiveness in implementing a program's policies; and (11) The effectiveness of work units in implementing policies for a program.

The effectiveness of face and finger access control is a measurement of the achievement of a predetermined goal, namely in relation to face and finger access control. Face and finger access control is a type of biometric attendance machine that uses employee fingerprints and face detection methods to record the attendance list of all employees. With this biometric attendance machine, it can be used to replace manual attendance machines.

Face and finger access control is equipped with a time recording feature. This feature allows us to know the timeliness of employees entering and leaving the office. For example, a company or agency has set the office hours at 07.35 . Then when an employee comes and makes attendance at 08:00, the biometric attendance machine will automatically record the employee's tardiness. This states that it is important for every company that wants to improve the discipline of its employees to use a fingerprint attendance machine such as face and finger access control.

In this study, the effectiveness of using face and finger access control at PT. PLN Tello Sector Makassar City will be analyzed based on criteria or indicators of effectiveness according to (Tangkilisan Nogi Hessel, 2015), namely: (1) Achievement of targets; (2) adaptability; (3) Job satisfaction; and (4) Responsibility.

\section{METHOD}

The location of this research is at PT PLN Tello Sector Makassar City to analyze the effectiveness of the use of face and finger access control. Researchers use this type of quantitative research with quantitative descriptive research type. The reason the researcher uses this type of research is because the researcher wants to describe the symptoms and events or events that have occurred factually, systematically, and accurately in the form of a percentage (Williams, 2007).

The population in this study are employees at PT. PLN Tello Sector Makassar City, amounting to 300 people. Due to the large population, the researcher decided to take a sample using the Taro Yamane formula, and obtained a total sample size of 75 employees. The technique of determining the sampling in research using the simple random sampling technique. The data collection technique chosen is to use a questionnaire (questionnaire) using a checklist form. The questionnaire is equipped with a measurement scale to produce quantitative data. The Likert scale will be used in this study to measure the attitudes, opinions and perceptions of employees or respondents at PT. PLN Tello Sector Makassar City regarding the effectiveness of using face and finger access control. 
The research questionnaire made by this researcher has been tested for validity and reliability before and after the study. The validity test uses the help of SPSS version 24.0 software. Validity testing is enough to compare the rcount value with the Product Moment $r$ table value (see Appendix). If the value of rcount $\geq$ rtable, the indicator or questionnaire statement is said to be valid, and vice versa. The data is also said to be valid if the value is sig. (2-tailed) data $<0.05$.

\section{RESULT AND DISCUSSION}

To be able to provide a description of the effectiveness of the use of face and finger access control that has been provided by PT. PLN Tello Sector Makassar City to employees during working hours. So the analysis in this study is focused on 4 (four) predetermined indicators of effectiveness, namely: (1) achievement of targets; (2) adaptability; (3) Job satisfaction; and (4) Responsibility. Each of these indicators has several instrument items (Endang \& Irma, 2014).

The first indicator of the effectiveness of the use of face and finger access control in this study is the target achievement factor owned by PT. PLN Tello Makassar City Sector, which is measured through 2 (two) instruments, which are related to: (1) Face and Finger Access Control implementation according to the objectives of PT. PLN Tello Sector Makassar City; and (2) Face and Finger Access Control implementation is achieved according to the target of PT. PLN Tello Sector Makassar City.

The results of descriptive analysis of the effectiveness of the use of face and finger access control with indicators of target achievement received an average rating from respondents of $64.05 \%$ strongly agree, $31.95 \%$ agree, $4 \%$ disagree, $0 \%$ disagree, and $0 \%$ strongly disagree. agree. Based on these data, the effectiveness of the use of face and finger access control from PT. PLN Tello Sector in Makassar City with indicators of target achievement received 3 (three) average assessment statements from 75 (seventy five) respondents, namely 64.05\% strongly agree, consisting of $70.7 \%$ or 53 (fifty three) ) respondents who strongly agree on instrument 1 and $57.4 \%$ or 43 (forty three) respondents who strongly agree on instrument 2, 31.95\% agree statements consisting of $25.3 \%$ or 48 ( forty-eight) respondents who gave a statement agreeing on instrument 1 and $38.6 \%$ or 48 (forty eight) respondents who gave a statement agreeing on instrument 2, $4 \%$ disagree statement consisting of $4 \%$ or 3 (three) respondents who gave a statement disagreeing with instrument 1 and $4 \%$ or 3 (three) respondents who gave a statement disagreeing with instrument 2 on the achievement of targets owned by PT. PLN Tello Sector Makassar City.

This describes that in general the PT. PLN Tello Sector Makassar City has achieved good targets in actualizing the effectiveness of the use of face and finger access control for employees, namely with an average rating of $64.05 \%$ respondents who gave a statement strongly agree.

Of the 2 (two) instruments used to measure the indicators of achieving the target of PT. PLN Tello Sector Makassar City, effectiveness of Face and Finger Access Control at PT. PLN Tello Sector Makassar City, implemented according to the objectives of the organization (company) which is the first instrument, deserved good appreciation from the respondents. This is because the employee attendance process is more modern and employee attendance is more increasing than before, thus giving better changes in terms of employee attendance and achieving the goals of PT. PLN Tello Sector Makassar City in carrying out its work activities.

Good statements from respondents regarding the achievement of targets on the effectiveness of the use of face and finger access control that have been provided by PT PLN Tello Sector Makassar City which are reflected through the implemented instruments according to the organizational goals (company), when linked to the concept of effectiveness according to 
(Siagian, 2015) that effectiveness emphasizes the results achieved, while efficiency looks more at how to achieve the results achieved then compares between the input and output, then this means that the first instrument in the target achievement indicator has shown a good level of achievement of results. So that this has a positive impact on increasing the attendance of employees according to the goals of PT. PLN Tello Sector Makassar City.

The second instrument used to measure the indicators of achieving the target of PT. PLN Tello Sector in Makassar City is the application of face and finger access control in this office is achieved according to the target of the organization, has shown a good level. This is because it has had a positive impact on employee attendance and morale so that it is almost in line with the company's targets. Another factor in the achievement of an organization or company target is due to an increase in employee performance in achieving company targets at PT. PLN Tello Sector Makassar City. This has a positive impact on the effectiveness of using face and finger access control at PT. PLN Tello Sector Makassar City.

Statements from respondents regarding the achievement of targets that have been given by PT. PLN Tello Sector Makassar City which is reflected through the application of face and finger access control in this office is achieved according to organizational targets, when linked to the concept of effectiveness according to Siagian (2015: 24), that effectiveness emphasizes the results achieved, while efficiency looks more at how to do it. achieve the results achieved then compare the input and output, so this means that the second instrument has been included in the good category at the level of achievement of the results according to the organizational targets that PT. PLN Tello Sector Makassar City.

It is different with the results of research conducted by (Maeyasari, 2012) entitled the effect of the effectiveness of the application of finger print attendance on the discipline of Civil Servants at the Regional Secretariat of Lebak Regency, which uses the same indicators in the effectiveness variable, namely according to Tangkilisan (2015) which results The target achievement indicator is said to be good enough so that it can be concluded that the application of finger print attendance is quite good in influencing the achievement of targets to be achieved by Civil Servants at the Regional Secretariat of Lebak Regency in terms of the existing percentage.

The second indicator of the effectiveness of the use of face and finger access control in this study is the adaptability factor possessed by PT. PLN Tello Sector Makassar City, as measured by 2 (two) instruments, relating to: (1) Easy to understand usage by all employees of PT. PLN Tello Sector Makassar City; and (2) Modern attendance machines which are accurate in inputting the attendance data of employees of PT. PLN Tello Sector Makassar City.

The results of the descriptive analysis of the effectiveness of the use of face and finger access control with the indicator of adaptation ability received an average rating from respondents of $64 \%$ strongly agree, $33.3 \%$ agree, $2.7 \%$ disagree, $0 \%$ disagree, and $0 \%$ strongly disagree. agree. Based on the data in Table 4.2, the effectiveness of using face and finger access control from PT. PLN Tello Makassar City Sector with the indicator of adaptation ability received 3 (three) average assessment statements from 75 (seventy five) respondents, namely $64 \%$ strongly agree, consisting of $64 \%$ or 48 (forty eight) respondents who gave statement strongly agree on instrument 1 and $64 \%$ or 48 (forty eight) respondents who give a statement strongly agree on instrument 2, 33.3\% agree statement consisting of 33.3\% or 25 (twenty five) respondents who giving a statement agreeing on instrument 1 and $33.3 \%$ or 25 (twenty five) respondents who gave a statement agreeing on instrument 2, 2.7\% disagree statement consisting of $2.7 \%$ or 2 (two) respondents who gave a statement disagreeing with instrument 1 and $2.7 \%$ or 2 (two) respondents who gave a statement disagreeing with instrument 2 on the adaptability of face and finger access control owned by PT PLN Tell Sector o in the city of Makassar. 
This describes that in general the PT. PLN Tello Sector Makassar City has good adaptability in actualizing the effectiveness of the use of face and finger access control for employees, namely with an average rating of $64 \%$ of respondents who give a statement that they strongly agree.

Of the 2 (two) instruments used to measure the indicator of the adaptability of PT. PLN Tello Sector Makassar City, the effectiveness of using face and finger access control in the PT. PLN Tello Sector Makassar City, easy to understand its use by all employees which is the first instrument, it deserves good appreciation from the respondents. This is because employees are easier in the attendance process so that they are no longer inconvenient for recording or reporting individually on the attendance of each employee besides that, the attendance process does not take long and does not bother employees.

A good statement from the respondent regarding the adaptability to the effectiveness of the use of face and finger access control that has been provided by PT. PLN Tello Makassar City sector which is reflected through an easy-to-understand instrument for use by all employees, when linked to the concept of effectiveness according to Tangkilisan (2015), where the ability to adapt is necessary in an organization because the success of an organization can also be seen from the extent to which an organization is able to adapt. with the changes that occur, be it changes from within the organization (internal) and outside the organization (externally). So this means that the first instrument in the indicator of adaptability has shown a good level that is easy to understand its use. So that this has a positive impact on increasing employee attendance according to the goals of PT. PLN Tello Sector Makassar City.

The second instrument used to measure the indicator of the adaptability of PT. PLN Tello Sector Makassar City modern attendance machines that are accurate in inputting employee attendance data, have shown a good level. This is because the attendance conducted by employees is accurate in inputting data that is directly connected to the Central PLN in Jakarta. In addition, employee attendance data is input systematically and makes it easier for companies to report their attendance data. This has a positive impact on the effectiveness of using face and finger access control at PT. PLN Tello Sector Makassar City.

Statements from respondents regarding the achievement of targets that have been given by PT. PLN Tello Sector Makassar City which is reflected through modern attendance machines that are accurate in inputting employee attendance data, when linked to the concept of effectiveness according to Tangkilisan (2015), the ability to adapt is necessary in an organization because the success of an organization can also be seen from the extent to which an organization is able adapting to the changes that occur, be it changes from within the organization (internal) and outside the organization (externally). Based on this theory, the second instrument has been included in the good category at the level of accuracy in inputting the employee attendance data that PT. PLN Tello Sector Makassar City.

The same is the case with the results of research conducted by (Maeyasari, 2012)entitled the effect of the effectiveness of the application of finger print attendance on the discipline of Civil Servants at the Regional Secretariat of Lebak Regency, which uses the same indicators in the effectiveness variable, namely according to Tangkilisan (2015) which results are the adaptation ability indicator is said to be quite good, and employees give a good attitude or agree with the application of finger print attendance.

The third indicator of the effectiveness of the use of face and finger access control in this study is the job satisfaction factor of PT. PLN Tello Sector Makassar City, as measured by 2 (two) instruments, relating to: (1) Providing comfort for employees of PT. PLN Tello Sector Makassar City in doing attendance; and (2) Provide motivation for employees of PT. PLN Tello Sector Makassar City to be more disciplined in time. 
The results of descriptive analysis of the effectiveness of the use of face and finger access control with job satisfaction indicators get an average rating of the respondents of $74 \%$ strongly agree, $26 \%$ agree, $0 \%$ disagree, $0 \%$ disagree, and $0 \%$ strongly disagree. Based on the data in Table 4.3, the effectiveness of using face and finger access control at PT. PLN Tello Sector Makassar City with job satisfaction indicators received 2 (two) average assessment statements from 75 (seventy five) respondents, namely $74 \%$ strongly agree, consisting of $77.3 \%$ or 58 (fifty eight) respondents who gave a statement strongly agreeing on instrument 1 and $70.7 \%$ or 53 (fifty three) respondents who gave a statement strongly agreeing on instrument 2 , then $26 \%$ agreed statement consisting of $22.7 \%$ or 17 (seventeen) people respondents who gave a statement agreeing on instrument 1 and $29.3 \%$ or 22 (twenty two) respondents who gave a statement agreeing on instrument 2 for the job satisfaction owned by PT. PLN Tello Sector Makassar City.

This describes that in general the PT. PLN Tello Sector Makassar City has had good job satisfaction in actualizing the effectiveness of the use of face and finger access control to employees, namely with an average rating of $74 \%$ respondents who gave a statement strongly agree.

Of the 2 (two) instruments used to measure the indicators of job satisfaction at PT. PLN Tello Sector Makassar City, the effectiveness of using face and finger access control in the PT. PLN Tello Sector Makassar City, the factor of providing comfort for employees in doing attendance which is the first instrument, deserves good appreciation from the respondents. This is because employees feel comfortable in doing attendance, do not bother employees to take notes and are very practical to use. Providing comfort for employees in doing attendance is an effectiveness of face and finger access control based on job satisfaction indicators, which in turn has a very positive impact on the effectiveness of using face and finger access control and gets good appreciation from employees (Hülsheger et al., 2013).

Good statements from respondents regarding job satisfaction on the effectiveness of the use of face and finger access control that has been provided by PT. PLN Tello Makassar City Sector which is reflected through the comfort instrument for employees in doing attendance, when it is related to the concept of effectiveness according to job satisfaction is a condition that is felt by all members of an organization or employees in an institution that are able to provide a sense of comfort and motivation. on improving the performance of organizations or agencies. then this can prevent employee dissatisfaction because of the feeling of inconvenience in doing attendance (Proctor, 2014).

So this means that the first instrument in the indicator of job satisfaction has shown a good level that provides comfort for its use. So that this has a positive impact on the comfort of employees in doing absences at PT. PLN Tello Sector Makassar City.

The second instrument used to measure job satisfaction indicators at PT. PLN Tello Sector Makassar City, a factor providing motivation for employees to be more disciplined with time, has shown a good level. This is because employees feel motivated to be more disciplined with time so that it has a positive impact on employees and the company (Lin, 2007).

Statements from respondents regarding job satisfaction that have been given by PT. PLN Tello Makassar City Sector which is reflected through providing motivation for employees to be more disciplined in time, when associated with the concept of effectiveness according to (Tangkilisan Nogi Hessel, 2015), job satisfaction is a condition that is felt by all members of the organization or employees in an institution that are able to provide a sense of comfort and motivation to increase the performance of the organization or agency. So this can prevent employee motivation to be more disciplined in time so that it has a positive impact in increasing employee motivation at work and maintaining discipline for each employee of PT. PLN Tello Sector Makassar City. 
The same is the case with the results of research conducted by (Maeyasari, 2012) entitled the effect of the effectiveness of the application of finger print attendance on the discipline of Civil Servants at the Regional Secretariat of Lebak Regency, which uses the same indicators in the effectiveness variable, namely according to (Tangkilisan Nogi Hessel, 2015)which results are The job satisfaction indicator is said to be quite good, this is based on the conclusion of the different job satisfaction of employees so that it is in a fairly good level.

The fourth indicator of the effectiveness of the use of face and finger access control in this study is the responsibility factor possessed by PT. PLN Tello Makassar City Sector, as measured by 2 (two) instruments, relating to: (1) Carrying out work in accordance with applicable regulations; and (2) Resolving problems that occurred at PT. PLN Tello Sector Makassar City.

The results of the descriptive analysis of the effectiveness of the use of face and finger access control with the indicator of responsibility received an average rating from the respondents of $37.3 \%$ strongly agree, $48.7 \%$ agree, $14 \%$ disagree, $0 \%$ disagree, and $0 \%$ strongly disagree. agree. Based on the data in Table 4.4, the effectiveness of using face and finger access control from PT. PLN Tello Sector Makassar City with responsibility indicators received 3 (three) average assessment statements from 75 (seventy five) respondents, namely $37.3 \%$ strongly agree, consisting of $41.3 \%$ or 31 (thirty one) Respondents who strongly agreed on instrument 1 and $33.3 \%$ or 25 (twenty five) respondents who strongly agreed on instrument 2, $48.7 \%$ agreed statements consisting of $57.4 \%$ or 43 (four thirty three) respondents who gave a statement agreeing on instrument 1 and $40 \%$ or 30 (thirty) respondents who gave a statement agreeing on instrument $2,14 \%$ disagree statement consisting of $1.3 \%$ or 1 (one) respondent who gave a statement disagreeing with instrument 1 and $26.7 \%$ or 20 (twenty) respondents who gave a statement disagreeing with instrument 2 for the responsibilities held by PT. PLN Tello Sector Makassar City.

This describes that in general the PT. PLN Tello Sector Makassar City has a poor responsibility in actualizing the effectiveness of the use of face and finger access control to employees, namely with an average rating of $37.3 \%$ respondents who gave a statement that they strongly agree.

Based on the results of the average value of each indicator in variable $\mathrm{X}$, namely $64.05 \%$ (first indicator), 64\% (second indicator), 74\% (third indicator), and 37.3\% (fourth indicator), the average value -The average of the four indicators is $59.8 \%$ in the quite good category.

Of the 2 (two) instruments used to measure the indicator of the responsibility of PT. PLN Tello Sector Makassar City, the effectiveness of using face and finger access control in the PT. PLN Tello Sector Makassar City, the factor of carrying out work in accordance with applicable regulations which is the first instrument, received a bad appreciation from the respondents. This is because there are still employees who carry out work not in accordance with applicable regulations. This does not have a positive influence on the effectiveness of the use of face and finger access control at PT. PLN Tello Sector Makassar City, so it is still not good enough.

The respondent's unfavorable statement regarding the responsibility for the effectiveness of the use of face and finger access control that has been provided by PT. PLN Tello Makassar City Sector which is reflected through the instruments of carrying out work in accordance with applicable regulations, when linked to the concept of effectiveness according to (Tangkilisan Nogi Hessel, 2015), the organization can carry out the tasks and authorities it has carried out in accordance with the provisions that have been made next, and be able to face and resolve various problems that occur in his work. So this is enough to prevent poor performance for employees and prevent a large error rate in completing work even though it is still in the poor category. 
The second instrument used to measure the responsibility indicator at PT. PLN Tello Sector Makassar City, a factor in solving problems that occur in the company, has shown to be at a less than good level. This is because employees feel that the problem is rarely resolved with the presence of face and finger access control so that it does not have a positive influence on the effectiveness of using face and finger access control at PT. PLN Tello Sector Makassar City so it is still said to be not good.

Makassar City which is reflected through solving problems that occur in the company, if it is related to the concept of effectiveness according to (Tangkilisan Nogi Hessel, 2015), the organization can carry out the tasks and authorities it has carried out in accordance with the provisions that have been made next, and be able to face and resolve various problems that occur in his job. Based on this theory, it cannot be said that it is appropriate because the answers from the respondents can be concluded that it is still not good in solving problems that occur in the company through the responsibility indicator at PT. PLN Tello Sector Makassar City.

The same is the case with the results of research conducted by (Maeyasari, 2012) entitled the effect of the effectiveness of the application of finger print attendance on the discipline of Civil Servants at the Regional Secretariat of Lebak Regency, which uses the same indicators in the effectiveness variable, namely according to (Tangkilisan Nogi Hessel, 2015)which results in The responsibility indicator is said to be quite good, especially the responsibility for the decision to apply finger print attendance in the Civil Servants environment at the Regional Secretariat of Lebak Regency.

\section{CONCLUSION}

Based on research results and discussion of research results regarding the analysis of the effectiveness level of the use of face and finger access control at PT. PLN Tello Sector Makassar City, it can be concluded that the level of effectiveness of the use of face and finger access control at PT. PLN Tello Sector Makassar City is in the fairly good category, based on the analysis of indicators of target achievement, adaptability, job satisfaction, and responsibility.

\section{REFERENCES}

Akman, I., Yazici, A., Mishra, A., \& Arifoglu, A. (2005). E-Government: A global view and an empirical evaluation of some attributes of citizens. Government Information Quarterly, 22(2), 239-257.

Bardach, E., \& Patashnik, E. M. (2019). A practical guide for policy analysis: The eightfold path to more effective problem solving. CQ press.

Bazen, A. M., \& Gerez, S. H. (2002). Achievements and challenges in fingerprint recognition. In Biometric Solutions (pp. 23-57). Springer.

Endang, P., \& Irma, P. S. (2014). The affect of work environment, job satisfaction, organization commitment on OCB of internal auditors. International Journal of Business, Economics and Law, 5(2), 10-18.

Farida, U. (2017). Analysis of Empowerment Program that was Implemented in Mamuju Regency East Sulawesi Indonesia. 149(Icest), 19-21.

Hadiana, R. N. (2019). The influence of transformational leadhership and commitment organization implications for performance employee State Civil Apparatus (Asn Bandung Indonesian). UNIVERSITAS PASUNDAN.

Hakim, A. (2012). Dinamika Manajemen Sumber Daya Manusia Dalam Organisasi. Efpres 
Digimedia.

Hülsheger, U. R., Alberts, H. J. E. M., Feinholdt, A., \& Lang, J. W. B. (2013). Benefits of mindfulness at work: the role of mindfulness in emotion regulation, emotional exhaustion, and job satisfaction. Journal of Applied Psychology, 98(2), 310.

Indrajit, R. E. (2016). Electronic Government: Konsep Pelayanan Publik Berbasis Internet dan Teknologi Informasi. Aptikom.

Ismail, A., Sulur, A. H., Akib, H., \& Salam, R. (2016). Snapshot of Society Social-Economic Welfare based on Human Development Index in Polewali Mandar Regency, Indonesia. International Conference on Public Organization VI (ICONPO VI), 847-858.

Jain, A. K., Nandakumar, K., \& Ross, A. (2016). 50 years of biometric research: Accomplishments, challenges, and opportunities. Pattern Recognition Letters, 79, 80-105.

Lee, L. T., \& Sukoco, B. M. (2007). The effects of entrepreneurial orientation and knowledge management capability on organizational effectiveness in Taiwan: the moderating role of social capital. International Journal of Management, 24(3), 549.

Lin, H. (2007). Knowledge sharing and firm innovation capability: an empirical study. International Journal of Manpower.

M. Konisky David, T. C. B. (2001). Innovations in public participation and environmental decision making: examples from the Great Lakes region. Society \& Natural Resources, 14(9), 815-826.

Maeyasari. (2012). Pengaruh efektivitas penerapan Absensi Finger Print Terhadap Disiplin Pegawai Negeri Sipil di Sekretariat Daerah.

Mohd, A., Ortjohann, E., Schmelter, A., Hamsic, N., \& Morton, D. (2008). Challenges in integrating distributed energy storage systems into future smart grid. 2008 IEEE International Symposium on Industrial Electronics, 1627-1632.

Priyono, M. (2016). Manajemen Sumber Daya Manusia. Zifatama Publisher.

Proctor, C. R. (2014). Effective organizational communication affects employee attitude, happiness, and job satisfaction. Southern Utah University. Department of Communication. 2014.

Sahlin-Andersson, K. (2011). Imitating by editing success: The construction of organizational fields. In Translating organizational change (pp. 69-92). de Gruyter.

Siagian. (2015). Peranan Staf dan Manajemen. Gunung Agung.

Siegel, D. S., Waldman, D. A., Atwater, L. E., \& Link, A. N. (2003). Commercial knowledge transfers from universities to firms: improving the effectiveness of university-industry collaboration. The Journal of High Technology Management Research, 14(1), 111-133.

Sunarsi, D. (2019). Analisis Pengaruh Lingkungan Kerja dan Budaya Organisasi Terhadap Kinerja Serta Implikasinya pada Kepuasan Kerja Guru Sekolah Dasar Di Wilayah Kabupaten Bogor-Jawa Barat.

Sunarsi, D., \& Erlangga, A. (2020). The Effect of Leadership Style and Work Environment on the Performance of Stationary Pump Operators in the Water Resources Office of West Jakarta City Administration. International Journal of Advances in Social and Economics, 2(3). 
266 Pinisi Discretion Review

Volume 4, Issue 2, March 2021 Page. 255- 266

Tangkilisan Nogi Hessel. (2015). Manajemen Publik. Gramedia Widiasarana.

Williams, C. (2007). Research methods. Journal of Business \& Economics Research (JBER), $5(3)$.

Zainal, H., Parinsi, W. K., Hasan, M., Said, F., \& Akib, H. (2018). The influence of strategic assets and market orientation to the performance of family business in Makassar City, Indonesia. Academy of Strategic Management Journal, 17(6). 